\title{
Integrative approach to a patient following rumenotomy - case report
}

[Abordagem integrativa ao paciente submetido à ruminotomia - relato de caso]

\author{
R.A.S. Oliveira' ${ }^{1}$, V.P. Souza ${ }^{2}$, A.C. Dantas ${ }^{3}$, J.A. Guimarães ${ }^{3}$, H.R. Lima $^{4}$, \\ R.S. Siqueira Filho ${ }^{3}$, E.R. Lima $^{3}$
}

\author{
${ }^{1}$ Aluno de pós-graduação- Universidade Federal Rural de Pernambuco - campus Recife - Recife, PE \\ ${ }^{2}$ Postgraduate student - Oregon State University - Corvallis, U.S.A \\ ${ }^{3}$ Universidade Federal Rural de Pernambuco - campus Recife - Recife, PE \\ ${ }^{4}$ Secretaria da Fazenda do Estado de Pernambuco, Recife, PE
}

\begin{abstract}
Concern with antimicrobial resistance in animal production systems increases the interest toward integrative therapies. The objective of the present report was to report an integrative approach to a goat undergoing rumenotomy. A goat with ruminal acidosis underwent rumenotomy, corrective rumen suture, moxibustion, and treatment of the surgical wound (TFO) with sugar. In the first twenty days, acupuncture was performed on ST36, indirect moxibustion on Sp6 and CV8, and TFO with antibiotic ointment and sugar. The wound contracted $2 \mathrm{~cm}$, there was gradual return of ruminal dynamics, and moderate pain. Acupuncture continued from D21 to D50 on Yin tang, BL13, BL20, BL23, and BL22. Although there was drainage of ruminal fluid, the wound contracted $4 \mathrm{~cm}$ during this period, pain was absent, and ruminal dynamics normal. During the last thirty days, the acupuncture technique surround the dragon was used and BL13 point needled, with complete closure of the wound. The TFO from D21 was performed solely with sugar. During treatment, there was modulation of the inflammatory response, with formation of granulation tissue and neovascularization. On D84, fibrinogen was $100 \mathrm{mg} / \mathrm{dL}$. The authors conclude that the use of sugar, acupuncture, and moxibustion contributed to return of normal ruminal motility, wound contraction, and complete tissue reepithelization.
\end{abstract}

Keywords: traditional Chinese medicine, acupuncture, moxibustion, surgical wound, ruminant

\section{RESUMO}

A preocupação com a resistência antimicrobiana nos sistemas de produção animal aumenta o interesse pelas terapias integrativas. Objetiva-se relatar a abordagem integrativa ao paciente caprino submetido à ruminotomia. Uma cabra com acidose ruminal foi submetida à ruminotomia, ruminorrafia, moxabustão, acupuntura e tratamento da ferida operatória (TFO) com açúcar. Nos primeiros vinte dias realizou-se acupuntura em ST36, moxa indireta em Sp6 e CV8, TFO com pomada antibiótica e açúcar. A ferida contraiu $2 \mathrm{~cm}$, houve retorno gradual da dinâmica ruminal e dor moderada. A acupuntura continuou de D21 a D50 em Yin tang, BL13, BL20, BL23 e BL22. Apesar da ferida drenar fluido ruminal teve contração de $4 \mathrm{~cm}$ nesse período, ausência de dor e retorno fisiológico da dinâmica ruminal. Nos últimos trinta dias foi realizada a técnica de acupuntura cercar o dragão e punturou-se o ponto BL13, com fechamento completo da ferida. O TFO a partir do D21 foi realizado somente com açúcar. Durante tratamento houve modulação da resposta inflamatória com formação de tecido de granulação e neoangiogênesse, o D84 revelou fibrinogênio $100 \mathrm{mg} / \mathrm{dL}$. Conclui-se que a utilização do açúcar, acupuntura e moxabustão contribuíram para o retorno fisiológico da motilidade ruminal, contração da ferida e completa reepitelização tecidual.

Palavras-chave: medicina tradicional chinesa, acupuntura, moxabustão, ferida cirúrgica, ruminante

Recebido em 26 de março de 2020

Aceito em 1 de setembro de 2020

E-mail: rhaysa.asoliveira@gmail.com 


\section{INTRODUCTION}

Lactic acidosis is a common disease in ruminant veterinary practice. Treatment protocols involve the use of drugs, conventional chemical products and, when needed, surgery (Khaskheli et al., 2020). Improper use of synthetic chemotherapeutic drugs in ruminants leads to transmission of antibiotic-resistant pathogens (PRA) to humans and deposits toxic residues in meat or milk. However, the growing tendency toward a more natural animal production system has stimulated interest in integrative and supplementary therapies (Acorda, 2018).

Integrative Veterinary Medicine includes complex medical systems, such as ethnomedicine and traditional Chinese medicine (MTC), where the latter includes acupuncture, moxibustion, and phytotherapy (Xie \& Preast, 2012). In China, the use of acupuncture and moxibustion in animals has been described since 221 B.C. (Schoen, 2006). Egyptian surgeons applied sugar to infected wounds since 1700 B.C. (Knutson et al., 1981). Advantages of these therapies are reducing the use of drugs that cause dependency, serious side effects, and antimicrobial resistance (Schoen, 2006). In spite of the benefits listed, in the Americas, there are scarce reports of acupuncture, moxibustion, and other supplementary practices in ruminant health (Acorda, 2018). As such, the objective of the present study is to report an integrative approach in a goat that underwent rumenotomy.

\section{CASE DESCRIPTION}

A four-month-old female pet goat (Capra hircus) of the Toggenburg breed, with brown and white coloring, small in size and weighing $13.5 \mathrm{~kg}$, raised in Recife, presented at the Veterinary Hospital of the Federal Rural University of Pernambuco (AGA/UFRPE). The main complaint was diarrhea and anorexia after eating $1 \mathrm{~kg}$ of pasta and $1 \mathrm{~kg}$ of rice. On clinical examination, the goat was observed to be standing, apathetic, with low head carriage, good nutritional status, body score of 3, tachycardia (96 bpm), tachypnea (48 $\mathrm{mpm}$ ), abdominal breathing, rectal temperature of $38.8^{\circ} \mathrm{C}$, skin turgor of 3 seconds, $5 \%$ dehydration, normal colored oral, nasal, and conjunctival (bilaterally) mucosae, moderately empty rumen, predominant liquid fraction, absent ruminal movements (auscultation over a period of 5 minutes), with only low frequency borborygmi, and tail dirty with soft feces.

An oral probe was not viable for emptying the rumen because of constant obstruction. During the procedure, the animal eliminated pellet-shaped feces which were normal in appearance. Upon analysis, ruminal fluid had a milky yellowishbrown color, acidic odor, slightly viscous consistency, $\mathrm{pH}$ of $4.0,0 \%$ live infusoria, methylene blue reduction test was negative at 10 minutes, sedimentation activity test time was 7 minutes, flotation (FLOT) did not occur at 10 minutes. Attempts to collect urine were unsuccessful. Because of the low $\mathrm{pH}$ of the rumen and the failed attempts at emptying it, rumenotomy was decided upon (D0). During surgery, approximately 2 liters of ruminal content (including rice) were removed. The surgical wound was cleaned with chlorhexidine gluconate and saline solution, treated with brown sugar and antibiotic ointment, and a bandage was placed over the site for protection, bid, for 20 days. An Elizabethan collar was used to prevent the animal from removing the bandages.

Using TCM to evaluate the patient, the goat had a slippery, thick, rapid, and superficial pulse, stronger on the right side of the second position. There was pain on palpation of the Spleen Shu, BL20 Pishu, and Triple Heater, BL22 Sanjiaoshu, points. Diagnosis using TCM consisted in dampheat invading the Spleen, Pí. Over the first twenty days, acupuncture was performed once daily with $0.25 \times 30 \mathrm{~mm}$ stainless steel needles on the master point of the gastrointestinal tract and abdomen, ST36 Zusanli, with a dispersion technique for 1 hour. Indirect moxibustion was applied to the Sp6-Sanyinjiao, and CV8- Shenque points, for 30 seconds sid, for tonification (Table 1).

Starting on the second day (D2), $20 \mathrm{ml}$ of water kefir were administered P.O., sid, for eight days. On the fourth day after surgery, the goat showed an appetite for green grass, and was observed to be ruminating and standing on the fourth day after surgery. Over the first ten days, the wound showed adequate healing, and was clean, dry, without draining secretions, and moderate pain on site (4/10), with rumen and muscle sutures preserved. Changes observed at the site of the wound were a slight seroma in the ventral region, skin suture dehiscence (D7), few crusts (D8), small amount of fibrin (D10), drainage of some 
serous secretion on D11 and ruminal fluid from D13. Evaluating the behavior, the goat was active (D11), with normal feces (D13). After 14 days, there was suture dehiscence and the animal had to undergo corrective closing of the rumen (D14).

The edges of the surgical wound were friable, which made it impossible to obtain proper approximation, thus a cannula ( $5 \mathrm{ml}$ syringe) was fixed to the skin and external oblique muscle, which connected the rumen to the exterior of the animal. Clinical examination eight days after surgery showed a moderately full rumen, illdefined stratifications, and ruminal dynamics with one complete and two incomplete movements in two minutes (Table 1, Figure 1).

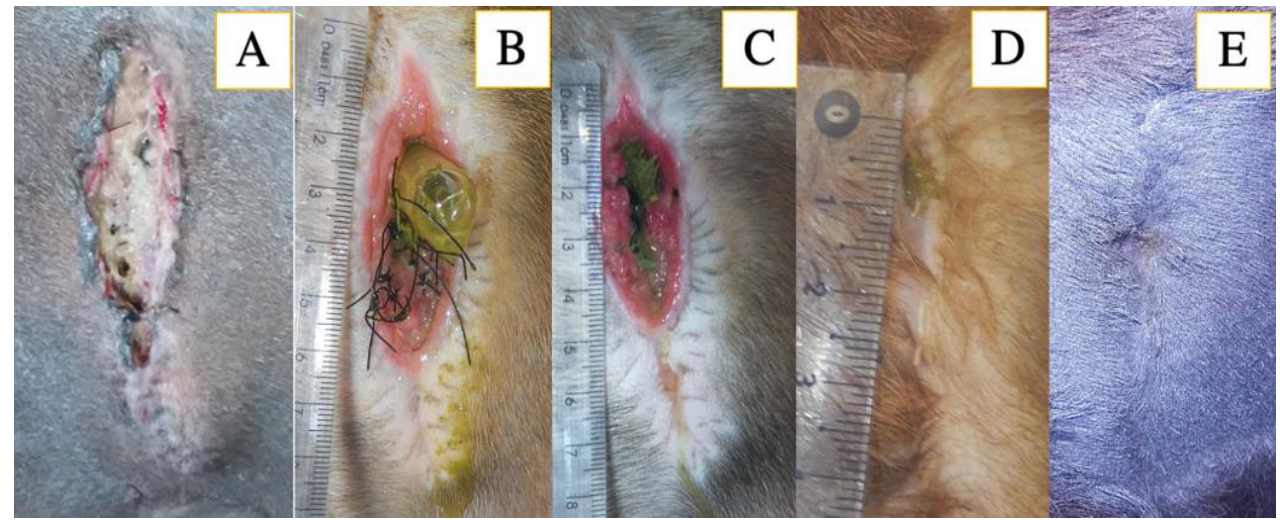

Figure 1. Evolution of surgical wound (FO) healing, in days (D), in a four-month-old female Toggenburg goat with ruminal acidosis, treated at the AGA/UFRPE in 2017 for 90 days. A: FO (D10) with contracted pink edges, slight seroma ventrally, skin suture dehiscence, few crusts, fibrin, and small amount of serous secretion drainage; B: FO (D23) with fistula present, contracted pink edges, dehiscence of the adjacent musculature, drainage of ruminal fluid and grass; C: FO (D28) with contracted pink edges, drainage of ruminal fluid and grass; D: FO (D64) complete reepithelization, fur growth on the site of the healed wound, small amount of drainage of ruminal fluid; E: FO (D90) complete tissue reepithelization.

Treatment with acupuncture continued from D21 to D50, with tonification for ten minutes of the Yin tang, BL13- Feishu, BL20- Pishu, and BL23Shènshu points and sedation for 40 minutes of the BL22- Sanjiaoshu point, both sid. Although there was drainage of ruminal fluid and grass through the wound until complete closure, contraction of the wound edges occurred rapidly, with $4 \mathrm{~cm}$ of contraction, absence of exudate, pink edges with good tissue regeneration and absence of pain on site (Figure 1). Starting on D51, to accelerate the healing process, the acupuncture technique surround the dragon and the BL13 point were used every day during 15 minutes. Complete wound closure occurred on the third month of treatment (Table 1).

The first hemogram showed hemoconcentration MCV: $41 \%(22-38 \%)$ and red blood cells $21 \times 10$ $\mathrm{x} 10^{6} / \mathrm{mL}$. On leukogram, there was leukocytosis $15120 / \mu \mathrm{L}$ with inversion $(10130 / \mu \mathrm{L}$ segmented neutrophils) and a regenerative left shift $(1210 / \mu \mathrm{L}$ bands), as well as hyperfibrinogenemia $(600 \mathrm{mg} / \mathrm{dL})$. After rumenotomy, the hemogram was normal. Fibrinogen values were at the upper limit $(400 \mathrm{mg} / \mathrm{dL})$, with hyperfibrinogenemia $(600 \mathrm{mg} / \mathrm{dL})$ the following day. On the sixth day, there was again leukocytosis $(6656 / \mu \mathrm{L})$ with inversion $(6656 / \mu \mathrm{L}$ segmented neutrophils), and on hemogram, a relative anemia was observed, MCV: $17 \%$ (22-38\%), also detected three days later, MCV: $18 \%$ (22-38\%), and in the last exam, MCV: $19 \%$ (22-38\%). Starting on day nine (D9), hematological parameters evaluated were mean corpuscular volume (MCV\%), proteins, and fibrinogen (Table 2).

The first fecal parasitology exam showed the presence of 600 epg of Strongyloidea, the second (D9), of 3200 epg of Strongyloidea and 400 epg of Trichuris spp, and the last, performed close to patient discharge, showed 700 oocysts of Eimeria spp and 2000 epg of Strongyloidea.

The benefits of the integrative therapeutic approach were observed at the end of the third month of hospitalization, with decreased pain during manipulation of the lesion, and good 
evolution of the healing process, with stimulation of angiogenesis and granulation tissue in the surgical wound. Anti-inflammatory and analgesic effects related to acupuncture, moxibustion, and the use of sugar were observed. In particular, recovery of ruminal dynamics, rumination, weight gain, and body development were noted. At the end of the treatment period, the surgical wound, which initially had eight centimeters in length by three centimeters in width and went from rumen to skin, had satisfactory tissue repair and fur growth on site (Figure 1; Table 1).

Table 1. Clinical and therapeutic evolution in days (D) in a four-month-old female Toggenburg goat with ruminal acidosis treated with allopathy and integrative medicine during 90 days at the AGA/UFRPE in 2017

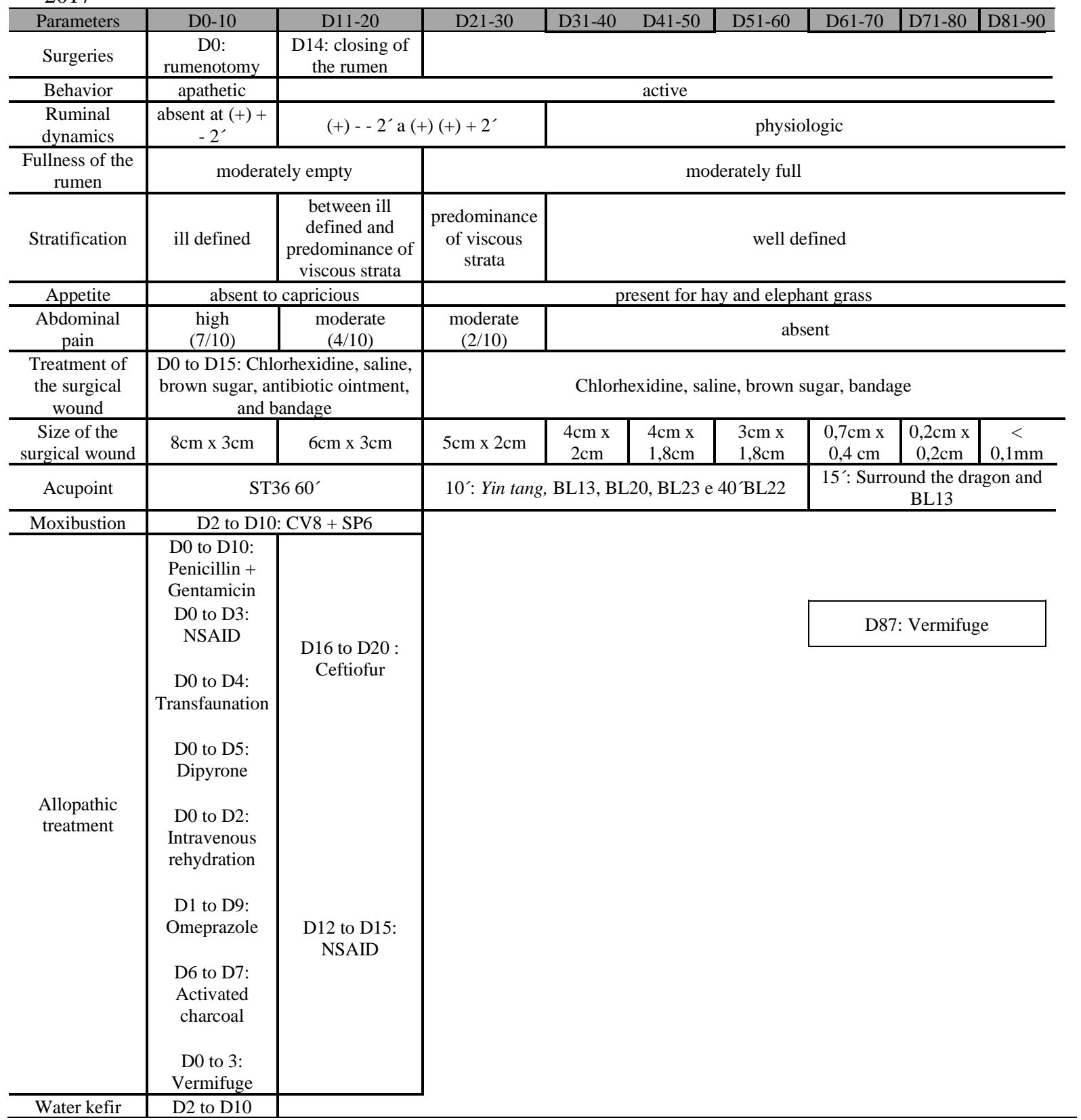


Table 2. Evolution of hemogram, leukogram, and fibrinogen parameters in a four-month-old female Toggenburg goat with ruminal acidosis treated with allopathy and integrative medicine during 90 days at the AGA/UFRPE in 2017

\begin{tabular}{lccccccc}
\multicolumn{1}{c}{ Parameters } & D0 & D2 & D3 & D6 & D9 & D84 & Normal values \\
\hline Hematocrit $(\%)$ & 41.0 & 25.0 & 22.0 & 17.0 & 18.0 & 19.0 & $22.0-38.0$ \\
Hemoglobin $(\mathrm{g} / \mathrm{dL})$ & $\mathrm{NP}$ & $\mathrm{NP}$ & $\mathrm{NP}$ & $\mathrm{NP}$ & $\mathrm{NP}$ & $\mathrm{NP}$ & $8.0-12.0$ \\
Red blood cells $\left(\mathrm{x} 10^{6} / \mathrm{mL}\right)$ & 21.0 & 15.0 & 13.8 & 9.3 & $\mathrm{NP}$ & $\mathrm{NP}$ & $8.5-18.0$ \\
MCV $(f \mathrm{~L})$ & 19.5 & 16.7 & 15.9 & 18.3 & $\mathrm{NP}$ & $\mathrm{NP}$ & $16.0-25.0$ \\
MCHC $(\%)$ & $\mathrm{NP}$ & $\mathrm{NP}$ & $\mathrm{NP}$ & $\mathrm{NP}$ & $\mathrm{NP}$ & $\mathrm{NP}$ & $30.0-36.0$ \\
Total leukocytes $(/ \mu \mathrm{L})$ & 15120 & 4300 & 5670 & 12800 & $\mathrm{NP}$ & $\mathrm{NP}$ & $4.0-13.0$ \\
Metamyelocytes $(/ \mu \mathrm{L})$ & 0 & 43 & 0 & 0 & $\mathrm{NP}$ & $\mathrm{NP}$ & Rare \\
Band neutrophils $(/ \mu \mathrm{L})$ & 1210 & 172 & 57 & 0 & $\mathrm{NP}$ & $\mathrm{NP}$ & Rare \\
Segmented neutrophils $(/ \mu \mathrm{L})$ & 10130 & 1849 & 2609 & 6656 & $\mathrm{NP}$ & $\mathrm{NP}$ & $30-40$ \\
Eosinophils $(/ \mu \mathrm{L})$ & 0 & 0 & 57 & 384 & $\mathrm{NP}$ & $\mathrm{NP}$ & $50-650$ \\
Basophils $(/ \mu \mathrm{L})$ & 0 & 0 & 0 & 0 & $\mathrm{NP}$ & $\mathrm{NP}$ & $0-1$ \\
Monocytes $(/ \mu \mathrm{L})$ & 303 & 86 & 226 & 128 & $\mathrm{NP}$ & $\mathrm{NP}$ & $0-550$ \\
Lymphocytes $(/ \mu \mathrm{L})$ & 3478 & 2150 & 2722 & 5632 & $\mathrm{NP}$ & $\mathrm{NP}$ & $2000-9000$ \\
TP $(\mathrm{g} / \mathrm{dL})$ & 10.0 & 4.2 & 5.0 & 5.7 & 6.2 & 5.2 & $6.0-7.5$ \\
PF $(\mathrm{mg} / \mathrm{dL})$ & 600 & 400 & 600 & 200 & 400 & 100 & $100-400$ \\
\hline
\end{tabular}

*NP: Not Available

\section{DISCUSSION}

In Western veterinary medicine, experiences with integrative practices involve mostly canines and equines (Schoen, 2006). This may be the reason why there are few descriptions of these treatments in the literature for ruminants. Studies show that complementary veterinary medicine is more effective than western medicine against functional and chronic disorders, pain, and inflammation (Acorda, 2018).

Treatment was based on eliminating local toxic heat, resolving humidity, and tonification of Spleen/Pí, Qì and of the Middle jiao (Sānjiāo). The Spleen shu and Triple Heater (Sānjiāo) points are the BL 20 and BL 22 points, respectively. According to TCM, the Triple Heater is divided into three energy centers, where the Middle jiao includes the region of the spleen, stomach, and liver. In ruminants, although chemical digestion is attributed to the abomasum, the rumen, reticulum, and omasum also participate in the digestion as fermentation chambers and are thus also under the energy control of Pí. The Middle jiao is associated with digestive and absorptive functions of the spleen and stomach, providing energetic support. The spleen transports and transforms food and fluids. Increased pain sensation in these points in this goat, added to the changes in pulse, are in agreement with what was described by Xie and Preast (2012) regarding changes in the digestive process, where the overconsumption of food led to an excessive increase in energy expenditure for digestion, thus depleting these organs, Zàng Fŭ.

The use of conventional therapy has been compared to the combination of conventional therapy and acupuncture for the treatment of ruminal acidosis, where recovery rate was significantly better with acupuncture (Mizuno and Tada, 1984). Acupuncture and moxibustion are easily performed in goats (Xie and Preast, 2011, 2012). The combination of acupuncture and drug therapy proved to be an advantage in bovine patients (Schoen, 2006). In the present report, a satisfactory clinical resolution was observed with the use of an allopathic and integrative treatment. The ST36 point has been used in bovines to regulate motility of the rumen (Schoen, 2006).

It has been proven that ST36 has a bidirectional modulating effect on electrical activity of the gastric muscle, possibly via M-cholinoceptors and $\alpha$-adrenoceptors (Zheng et al., 2011). Moxibustion is a method where Artemisia vulgaris wool is burned over the skin, over acupuncture points or more extensive areas where symptoms present. The heat and essence from the herb heat the $Q i$, increase blood flow (Xue), resolve mucosity, eliminate forms of toxic heat, and lead to the emission of electromagnetic radiation via infrared waves. Xie and Preast (2011) report that in domestic animals, indirect moxibustion over $\mathrm{CV} 8$ points act in reducing edema, abdominal distension and pain, extreme weakness, tonifies and strengthens the $Q i$ of the 
spleen, kidney, and stomach, and disperses humidity. The SP6 point has an effect on disorders of the digestive system, inflammatory intestinal disturbances, pain, and abdominal distension.

Sedation of the ST36 point and moxibustion at CV8 and SP6 probably contributed toward circulation of $Q i$, and dispersion of humidity and toxic heat from the stomach. This was observed in the gradual return of ruminal dynamics, from absent (D0) to (+) (+) + (D20); improvement of ruminal stratifications, from ill-defined (D0) to predominance of viscous strata (D20); as well as a reduction in pain, classified as moderate (4/10) between D11 and D20 (Table 1, Figure 1). The integrative therapy performed until D20 probably permitted a greater control of factors that predispose to wound infection, where few crusts only on D8, a 2-cm wound contraction, pain decrease to moderate $(4 / 10)$, and active behavior starting on D10 were observed (Figure 1).

Stimulus from electroacupuncture (EA) on the BL20 point in healthy goats increased the amplitude of ruminal and abomasal contraction detected via physiogram (Nam, 1997). Dehui et al. (2014) observed that the use of left unilateral electroacupuncture was effective at BL20 and BL22 points in bovines with ruminal impaction, leading to a significant increase in ruminal contractions, duration of ruminal contractions, concentration of ciliate protozoa in the ruminal fluid, as well as an increase in fermentation and vagal activity.

It is suggested that stimulation of BL20 and BL22 points led to a return of normal ruminal dynamics, fullness, and stratifications observed between D21 and D50, and also of normal appetite and active behavior. The animal was considered to be undergoing puberty during this period, and thus more needling points were available. Pain decreased from moderate $(2 / 10)$ to absent. This may be related to the acupuncture stimulus of the extra point Yìn táng, BL13, BL20, BL2, and BL23, which stimulated the increase of $\beta$ endorphin and cortisol, as well as provided pain relief, and reduced inflammation and muscle spasticity (Luna and Carregaro, 2019). Xie and Preast (2011, 2012) mention that these acupuncture points activate tissue factor XII, which in turn activates the complement cascade, degranulates mast cells, releases histamine, heparin, proteases, bradykinin, and increases blood flow (Xиe) and immunological response to the needling area, as well as muscle relaxation of the region.

The biochemistry of acupuncture involves a complex interaction of endogenous opioid components with substance $\mathrm{P}$, acetylcholine, serotonin, norepinephrine, and gamma aminobutyric acid (GABA) (Schoen, 2006; Xie and Preast, 2011). During the interval between D51 and D90, there was stabilization of the physiologic parameters within normal limits for the species, as well as gradual and significant healing, with a gradual decrease of ruminal fluid eliminated via the fistula and its complete closure. This was possibly related to the surround the dragon technique and stimulation of the BL13 point, which contributed toward tonification of the $Q i$ and blood, which exacerbated the tissue healing process surrounding the surgical wound.

Sugar has an antibacterial mechanism due to its hyperosmolarity, which dehydrates the bacterial cell and reduces edema. It also modulates the inflammatory response by stimulating macrophages and the rapid formation of granulation tissue (Rahal et al., 1982). Lima et al. (2012) observed similar effects using sugar in the treatment of a contaminated wound in an ovine. This effect was observed on D84, with fibrinogen at $100 \mathrm{mg} / \mathrm{dL}$ (Table 2) and between D21 and D90 (Table 1, Figure 1), it was also observed that the granulation tissue started at the margins, occupying the injured area, displaying a bright, granular, and intense red coloration, corresponding to neovascularization (Figure 1). Despite constant drainage of ruminal fluid, the healing process evolved in a satisfactory manner, with wound contraction by $5 \mathrm{~cm}$ until complete tissue regeneration, with no pain or inflammatory changes (Figure 1).

The authors suggest that the antibacterial action of the sugar, added to the analgesic and antiinflammatory effects of acupuncture, permitted treatment of the wound during this period (D21D90) without the need for other topic or systemic antibiotics or analgesic drugs. This decreased the costs and avoided secondary infections. An important factor in this case was the dedication of the professionals at the AGA/UFRPE, who were willing to adopt new possibilities in the form of complementary, integrative, and non- 
pharmacological treatments in veterinary medicine.

\section{CONCLUSION}

The authors conclude that the use of sugar, acupuncture, and moxibustion contributed to recovery of normal rumen motility, wound contraction, and complete tissue reepithelization. The authors note that further studies and in-depth clinical analysis for Western veterinarians regarding the contributions of integrative practices in ruminant health are needed.

\section{REFERENCES}

ACORDA, J.A. Applications of acupuncture in ruminant health and production. SEARCA Agricult. Dev. Disc. Paper Ser., v.2017, 29p., 2018.

DEHUI, S.; ZHAOCHUN, J.; JIEZHENG, Z. et al. The Effects of electro-acupuncture of pi-shu and du-jiao acupoints on ruminal movement and fluid in cattle with ruminal impaction. Am. J. Trad. Chi. Vet. Med., v.9, p.69-74, 2014.

KHASKHELI, A.A.; MUHAMMAD, I.K.; KHASKHELI, A.J.; KHASKHELI, A.A. A mini review on the Lactic Acidosis in goats and its remedial approaches. Aceh Journal of Animal Science, v.5, p.98-103, 2020.

KNUTSON, R.A.; MERBITZ, L.A.; CREEKMORE, M.A.; SNIPES, H.G. Use of sugar and povidone iodine to enhance healing: five years' experience. S. Med. J., v.74, p.1329$1335,1981$.
LIMA, D.C.M.; GONÇALVES R.C.; TANAKA, N.M. et al. Açúcar cristal no processo cicatricial de ferida contaminada em ovino. UNOPAR Cient. Ciênc Biol Saúde, v.14, p.111-114, 2012.

LUNA, S.P.L.; CARREGARO, A.B. Anestesia e analgesia em equídeos, ruminantes e suínos. São Paulo: MedVet, 2019. 676p.

MIZUNO, S.; TADA, H. Toshoku ni yoru rumenacidosis ni taisuru junki-shin ryoho (kasho) no koka ni tsuitee. J. Vet. Clin., v.247, p.15-18, 1984.

NAM, T.C. Acupuncture therapy in food animals. 2.ed. Seoul: Kwangil publishing Co, 1997. 200p.

RAHAL, F.; MIMICA, I.; PEREIRA, V.; ATHIE, E. O açúcar no tratamento local das infecções de feridas cirúrgicas. Rev. Colégio Bras. Cir., v.10, p.135-136, 1982.

SCHOEN, A.M. Acupuntura Veterinária: da arte antiga à medicina moderna. 2.ed. Trad. Maria Inês Garbino Rodrigues. São Paulo: Roca, 2006. 598p.

XIE, H.; PREAST, V. Acupuntura veterinária xie. São Paulo: MedVet, 2011. 363p.

XIE, H., PREAST, V. Medicina veterinária tradicional chinesa: princípios fundamentais. São Paulo: MedVet, 2012. 640p.

ZHENG, J.; LUO, C.; QIN, Z. A preliminary study of cutaneous electrogastrograms before and during electro-acupuncture at ST-36 and the effects on M- cholinoceptors, alpha adrenoceptors and $\mathrm{H} 2$ histamine receptors. Am. J. Trad. Chin. Vet. Med., v.6, p.23-28, 2011. 